\title{
Articles
}

\section{Malcolm Ross and the Samoan 'troubles' of 1899}

\section{ABSTRACII}

New Zealand journalist Malcolm Ross was a witness to the international rivalries over Samoa between Germany, Britain and the United States, which came to a head in 1899. Civil war had broken out after the death of King Malietoa Laupepa in August 1898 over who would be his successor. The United States and Britain stepped in and supported Laupepa's son while Germany supported a rival claimant, Mataafa. Malcolm Ross went to Samoa in late January to report on the 'troubles' for three New Zealand daily newspapers, the Otago Daily Times, The Press and the Evening Post. The Samoan trip was Ross's first experience as a war correspondent, although not everybody saw the conflict as war. This article examines Ross's coverage of four months of the conflict until the cessation of hostilities when a three-man commission was established to look into the troubles and offer a solution. The article will assess Ross's work as a journalist in a 'war zone'. The freedom with which he was able to operate in Samoa was not to be repeated, especially once he had become the country's official war correspondent during World War I.

Keywords: conflict reporting, Malcolm Ross, Samoa, war correspondents

\section{ALLISON OOSTERMAN}

AUT University, Auckland

\section{Introduction}

7 HE FIRST opportunity for New Zealand journalists to cover war was the New Zealand Wars of the 1860s and several took advantage of

it. But when Malcolm Ross in 1899 travelled to Samoa to report on a conflict, he was one of the first New Zealand journalists to report on a war 
overseas. However, he was not the only one. Fred Carr Rollett of The New Zealand Herald was already in Samoa and James Cowan of the Auckland Star was to arrive not long after Ross. In February of 1899 Malcolm Ross received permission from his contracted papers to cover the disturbances in Samoa. There may be debate over whether these disturbances could be called 'war' but there was a state of armed conflict in Samoa, even if not directly between states or nations. The Imperial powers involved might like to have called it a civil war between rival Samoan factions, but when one power, Germany, supported one faction and two other powers, Britain and the US, supported the opposing one then it is justified to see the episode as more than a civil disturbance. The year of 1899 was significant, not only because Malcolm Ross provided despatches from the scene of fighting but because this was the year that the partitioning of Samoa was determined and New Zealand's hopes of a more permanent influence in Samoa were dashed. This was Ross's first foray into the genre of war correspondence and should provide a foretaste of what was to come later when he was sent to cover the fighting of the New Zealand troops in World War I.

\section{War correspondence in New Zealand before 1899}

Not much is known about New Zealand journalists' views on war correspondence but there was one indication to be found in a leading article of Dunedin's Otago Daily Times (ODT) on 28 August 1900 under the heading War correspondents. The leader noted that war correspondents at the turn of the century were now regarded as a 'necessary adjunct to a modern newspaper' but it was rather dismissive of the need to cover the conflict between Māori and white settlers. This does suggest that by 1900 a tradition of war correspondence had developed. This newspaper certainly appeared to think so.

In the early days, when war was waged in various parts of the North Island against the Māori, there were little or no opportunities for the war correspondent and recent enterprising journals in this colony devoted more attention to exploration and the opening up of new country for settlement than to warlike subjects. From time to time representatives of this journal have headed or taken part in many such expeditions. (Anonymous, 1900) 
For New Zealand's oldest daily newspaper, the New Zealand Wars must have slipped its memory if it could consider the Parihaka campaign of 1881 as 'the first real opportunity afforded in this colony to the war correspondent'. Edward T. Fricker represented the $O D T$ on that occasion. Of course, there were several northern journalists who covered the New Zealand Wars. A notable one was William Morgan, who worked out of Drury and sent reports to the Daily Southern Cross and occasionally the London Weekly Review, over a period of about six months (Morris, 1963). He is not mentioned in The Oxford companion to New Zealand military history (McGibbon, 2000, p. 678). As a young man Morgan began a journal a few days after leaving England in 1852. This journal forms the basis of the many published accounts he wrote during the war in the Franklin area from July 1863. His despatches were often published in other New Zealand newspapers. The Daily Southern Cross had other correspondents writing about the war, such as Charles Williamson. He covered the Waikato and Tauranga campaigns for the paper often with $\mathrm{H}$. Willoughby, the special correspondent representing the Melbourne Argus (Anonymous, 1883). As well, the editor, Robert James Creighton, spent some time in the field as a correspondent, according to Guy Scholefield (Scholefield, 1958, p. 78). The opposition paper in Auckland, The New Zealander, also fielded a war correspondent, albeit a volunteer one, John Sheehan, who later became Minister of Native Affairs (Anonymous, 1878).

Others that were cited by The Oxford Companion included G.W. Woon, the owner of the Taranaki Herald, who the editor believed could lay claim to the title of New Zealand's first war correspondent. 'As a member of a volunteer unit, he produced a journal of events based on the fighting in Taranaki from 1860 to 1861' (Anonymous, 2000, p. 578). Guy Scholefield recorded that Woon served his apprenticeship in the New Zealander's Wellington office before heading for Taranaki to become the nominal editor of the Taranaki Herald. He bought the paper in 1854 and was the editor for most of the time from then to 1867 (Scholefield, 1958, pp. 129-131). The regular Journal of events he published from 1860 at the commencement of the Waitara conflict was seen by Scholefield as a 'valuable source for the history of that period', since Woon was a member of the Rifle Volunteers 'and knew what was passing'. Other correspondents to cover the New Zealand Wars, says The Oxford companion, were W.D. Campbell (Lyttelton Times), Gustavus von Tempsky 
(Daily Southern Cross) and John Featon, who published a history of the Waikato campaign in 1879 (Featon, 1879). One could also point to Charles Otto Montrose who made his mark with letters from the front when he was a foot soldier with one of the regiments of the line during the wars. He later became the subeditor of the Auckland Star under T. W. Leys (Anonymous, 1907). A common feature of war correspondence of the time appeared to be journalists combining their newspaper work with their own military activity. That is certainly true of Woon, von Tempsky and Montrose. There are probably other men (and they were almost always men) as yet unresearched who covered the wars. So for The Oxford companion to claim Woon as the country's first war correspondent is probably premature considering so little research has been carried out on the subject.

Many New Zealanders in the late 19th century were inspired by the exploits of renowned war correspondents from Britain and elsewhere. William Russell of The Times, with his despatches from the Crimean War (Russell, 1855), was highly regarded. Later, such journalists as Archibald Forbes, who covered the Franco-Prussian War, in the early 1870s and the Russo-Turkish campaign of 1877 and Bennett Burleigh of the Glasgow Daily Mail were published widely in New Zealand. As well the country was often visited by war correspondents on lecture tours, one of them being Forbes himself in 1882 (Anonymous, 1882). Another war correspondent to visit was Howard Vincent, the special war correspondent for the Daily Telegraph with the British army in the Danube during the Russo-Turkish War of 1877 (Anonymous, 1884). He toured the country in October 1884. He was followed a year later by George Augustus Sala, of The Telegraph (Anonymous, 1885). Phil Robinson, the war correspondent with the Daily Chronicle visited New Zealand in 1888 and was extensively reported while in the country (Anonymous, 1888a, 1888b, 1888c). Next to make a speaking tour was David Christie Murray, war correspondent of the London Times (Anonymous, 1890a, 1890b) followed by H. M. Stanley, war correspondent in Abyssinia and finder of Livingstone (Anonymous, 1892). The final war correspondent of note to tour the country prior to the Samoan 'troubles' and the South African War in 1895 was Frederic Villiers, the veteran correspondent of the Standard who had witnessed the taking of Khartoum 10 years earlier (Anonymous, 1888a, 1895). War correspondents in those days were news in themselves. 


\section{Background to the Samoan 'troubles' of 1899}

In the period 1873 to the mid-1890s, Samoan politics, as I. C. Campbell tells it, were a 'confusing and chaotic process as settlers of different nationalities vied for pre-eminence' (Campbell, 1989, p. 99). European settlers, mainly British, German and American, sought land and influence and stirred up Samoan politics that were already riddled with inter-tribal strife. Even from 1875 when the first kingship was established, and Malietoa Laupepa became head of state, (Barclay, 1978, p. 114), unrest continued. Rivalries and jealousies amongst the European settlers saw Laupepa deposed and then reinstated as power seesawed from one group to another. Angus Ross said it became clear to all 'that annexation by one power was inevitable'. Foreign intervention in the internal politics and indigenous wars 'helped to make the troubled waters of Samoan affairs even more troubled' (A. Ross, 1964, p. 174). Campbell said that from 1876-1889 there were at least seven attempts to establish governments in Samoa, a major civil war and two smaller rebellions (Campbell, 1989, p. 99). The three major powers signed treaties of friendship with Samoa from 1878-79, all keen to keep their trading privileges and other advantages, such as land, coaling stations and naval bases (A. Ross, 1964, p. 173). The Samoans were increasingly concerned about the instability being generated by the Europeans tussling over their country, especially from the German quarter, and appealed to Britain, New Zealand and the US at various times to take them under their protection. Warships of the three powers were sent to Samoan waters and in 1889 at the Berlin Conference the independence of Samoa was upheld but the rights of the three powers also maintained (A. Ross, 1964, p. 208). The solution 'was obviously not a permanent one and was bound to be contested'. Things came to a head again in late 1898 when Laupepa died and a struggle over the succession between Mataafa and Laupepa's son, Tanumafili ensued (Barclay, 1978, p. 124). German interests supported the former and British and United States interests supported the latter. Barclay claimed Germany had been playing 'divide and rule' in Samoa by supporting one group of claimants over the other.

\section{New Zealand interest in Samoa before 1899}

According to Angus Ross, New Zealanders, led by those crusading imperialists, Julius Vogel, Sir George Grey and Dick Seddon, saw Samoa as the most important group of islands in the whole Pacific (A. Ross, 1964, 
p. 175). 'Grey, Vogel and others had already shown that they firmly believed that Samoa was just as important to New Zealand as New Guinea was to Australia.' To this end from the 1870 s on New Zealand tried to convince Britain to step in and offer protection to the tiny island nation and save it from the influence of other imperial powers, notably Germany and to a lesser extent, the United States (Barclay, 1978, p. 113). The interest was for commercial and strategic reasons. 'A tradition of mixed commercial, political and romantic origins continued to inspire new Zealand politicians to demand the annexation of Samoa before all other groups in the Pacific' (A. Ross, 1964, p. 176). Despite repeated hammerings on the doors of Downing St and Whitehall, or 'bleating', as Barclay called it (Barclay, 1978, p. 116), New Zealand got nowhere. 'Slowly but surely the folly of continuing to press for the annexation of Samoa was being brought home to the New Zealand leaders' and by mid-1885 it was clear Britain would not permit annexation (A. Ross, 1964, pp. 192-193). This did not stop New Zealand hankering after some role for itself in Samoa, but the inflated aspirations of New Zealand as a colonial power in the Pacific did not eventuate. Glen Barclay had a sceptical view of New Zealand motives.

Pākehā and Māori New Zealanders alike protested about the fate of the Samoans - with differing motives but precisely similar results. The $N Z$ Herald protested on the economic grounds that it was the destiny of New Zealand to become the emporium of the South Pacific and no European intrusions should be allowed to get in the way. A Māori MP objected to the German domination on the grounds that Māori and Samoans were one people and should not be politically separated. Twenty one Māori chiefs sent a letter of consolation to Laupepa deploring German methods. All of this of course made no difference whatsoever. (Barclay, 1978, p. 122)

\section{Malcolm Ross: the war correspondent and his despatches}

In January of 1899 George Fenwick, the managing director of the $O D T$, received a telegram from Ross in Wellington intimating he proposed leaving at once for Samoa to act as special correspondent for the ODT, The Press and the Evening Post. This was at a time when continuing disturbances were taking place over the election of a new king after the death of Laupepa on 22 August 1898 (Anonymous, 1899t). Ross said he estimated that 
costs would be well under $£ 50$. Fenwick telegraphed Ross to say the $O D T$ would share the expenses of the correspondent with the other two papers (Anonymous, 1895-1901). This is an interesting situation where it appeared to be Ross calling the shots and deciding what news he would cover and contrasts with his later position as official war correspondent in World War I. As a freelance he had more freedom to choose his assignments. Parliament was in recess and as long as he could get paid for whatever work he managed to find outside the sessions, he could do what he wanted. Fenwick and the ODT board did not always accede to Ross's applications for special assignments. This time they did, largely because the topic was of such interest to New Zealanders but also, one suspects, because the other large New Zealand daily, the NZ Herald, had a journalist at Apia.

Ross must have left straight away because his first despatch was published on 15 February 1899 in the $O D T$ and The Press having been sent from Apia on February 8 on the steamer Mariposa to Auckland from whence it was then telegraphed to each subscribing paper (M. Ross, 1899i, 1899p). It took about five days for the steamer to get from Apia to Auckland, so the news was still fairly fresh when it arrived in New Zealand. This first batch of stories was run over the next few days. That first report was published on the same day in The Press (M. Ross, 1899i) and the ODT (M. Ross, 1899p), but the presentation differed somewhat between the two papers. The Press story ran to more than 10,000 words over six columns and was continued the next day with a further 5000 words and the following day with around 3500 words. Ross began his despatch in The Press thus:

Another stage in the history of Samoa has been reached, and the curtain having just been rung down on a scene of bloodshed, pillage, and banishments, here now we are again in the midst of a comedy that some Gilbert and Sullivan might very well set to rhyme and music, were it not for the fact that tragedy still looms darkly ahead.

The $O D T$ story began in this manner:

Through seas of molten glass, gently heaving, a summer's sun above, and all around a narrow circle of horizon, at intervals with splendid masses of cloud, our ship, deep laden with coal and cargo, plugged steadily northward, and now our last morning with gorgeous tropic 
sunrise has come quickly over the placid waters, and the misty island looms ahead.

It is impossible to say why these intros were so dissimilar. The subeditor of either paper probably had something to do with it. The Press introduction was a much more promising one with an attempt at a summary intro but this then degenerated into too much verbiage - all 62 words of it. As for the $O D T$ intro, this sounds more like Ross as it appears more contrived. He then devoted several thousand words to describing the background to the 'troubles' before setting off, sometimes with the Herald reporter, Rollett, to interview the 'rebel King', Mataafa, the newly installed King, Malietoa Tanu and his vice-King, Tamasese. With all these Ross uses a mixture of reported speech and direct quotes, the latter not common for the times, according to Michael Schudson (Michael Schudson, 1995, p. 78). Direct quotes did not become common practice until after World War 1. Ross then interviewed Dr Raffel, the German president of the municipality, appointed by the Berlin Treaty powers, followed by the German Consul, the Chief Justice, the British Consul and finally the American Consul. Sometimes he mentioned the name of the various officials he spoke to, and other times it was just 'the Chief Justice', or 'the American Consul' (Rollett tended to do the same.) He concluded this marathon effort with his own review of the situation in Samoa. He said, after all that he had learned, he was 'forced to the conclusion' that the Berlin Treaty had been 'an absolute failure' and that in his view tripartite control would never be a success in Samoa. His solution was for either Britain or the US to annex the islands, although his and the Islanders preference was for Britain to do so. None wanted Germany, said Ross. 'The present extraordinary state of things should not be allowed to continue another day, and it would be well if the colonies took some prompt action in the matter.' Ross was echoing the opinion that had been expressed for several decades by New Zealand.

By March 1899 the conflict was becoming more inflamed and the US and British had resorted to bombarding Samoan villages from their warships out at sea. At the end of March, the New Zealand government offered the British the use of the government steamship Tutanekai to ship mails to Samoa and asked the British Secretary of State if it wished New Zealand to send 500 armed constabulary and two Maxim guns to help in restoring order 
(Anonymous, 1899r; Governor, 1899). The offer was repeated but speculation, rife in press circles, was that the offer of troops would not be accepted (Anonymous, 1899m, 1899u). It was not but the use of the Tutanekai was (Anonymous, 1899u; Hansard, 1899). According to the London correspondent of the $O D T$, the offer was being hailed with 'delight' in London as evidence of the strength of the Imperial spirit (Anonymous, 1899k). The Observer ridiculed the Auckland Volunteers for their keenness to get into a fight with the Samoans. The paper accused Premier Seddon and Major Murray of the volunteers of being 'desperately eager to win a cheap renown by embroiling New Zealand in this miserable war against a party of half naked and poorly armed Samoans, who have been egged on by German instigation to stand by what they believe to be their rights' (Anonymous, 1899b). The Taranaki News asked what Samoan ever did an Auckland Volunteer so much harm that he should be 'dying to go over and cut a few native throats' (Anonymous, 1899v). The Australians were either entertained or sobered by New Zealand's offer of troops. The Melbourne Argus said New Zealand's eagerness to 'get mixed up' in the Samoan hostilities was 'likely to cause as much amusement as admiration, perhaps more' (Anonymous, 1899y). Sydney's Freeman's Journal was sombre.

It would have been a sorry exhibition, to have witnessed troops from New Zealand - the home of democracy-engaged in the task of suppressing an effort of a free people to enthrone the ruler of their choice. (Anonymous, 1899v)

The Press saw the offer of troops in a much more serious and positive vein. If accepted, the offer would 'mark a new era' in New Zealand's history, it said. New Zealand now recognised its responsibilities as a part of the British Empire (Anonymous, 1899c). The NZ Herald was equally overcome by the import of the offer of troops. 'The proposal to dispatch troops to Samoa is a new revelation to the world of the power of the British Empire,' said a leader (Anonymous, 1899w). It did not actually believe the offer would be accepted, however, but the gesture was obviously thought to be enough to show the Mother Country it had New Zealand's support. These were imperialistic views when compared with those of The Observer which, weighed into the debate with a leader under the heading The Samoan bungle. 
It is really high time that Great Britain, the United States and Germany retired from Samoa and allowed the natives to try and govern themselves. Since those three powerful Christian nations first meddled in the islanders affairs their mutual jealousies and pitiful bungling have kept the unfortunate aborigines in a state of continual ferment and have led to much effusion of bloods into a condition closely resembling anarchy. (Anonymous, 18991)

The paper had already published a cartoon on its front page on 23 January 1899 lampooning the three powers (Blomfield, 1899).

Ross filed extensive despatches in March on the fighting (M. Ross, 1899c, 1899d, 1899e, 1899n, 1899o, 1899q, 1899w, 1899y). He was able to go virtually where he pleased and write what he wanted. As The Press commented in one of its leaders on the situation, Ross 'very pluckily went to the front, in the very thick of the fighting, and he has sent us a very graphic picture of the conditions under which the war is being carried on' (Anonymous, 1899x). This included tales of lootings, beheadings, bombardments, forays into the jungle and the like.

Gaunt's men had sallied out again after the shelling, and the rebels poured a hot fire at them. The aim was low, and not many bullets came over us. On the left of the road I found the captured forced thick with the friendlies. On the right were others, and here I spied the British Consul Dr Odell from the American flag ship and Mr Hall (the most daring of the interpreters). I crept up to them, and gleaned a few particulars of the position, but it was difficult conversing in ordinary tones so loud and continuous was the rattle of the rifles. Lieutenant Gaunt was just in front of our fort and only 150 yards from the enemy. He had crawled on his stomach to within 30 yards of the rebel entrenchment. He found it thick and strong, with loopholes for the rifleman, and it extended a long way through the bush. I attempted to take a couple of photographs, and then dodged back to cover. A wounded man went past on the back of a comrade. Another dropped and was hurried back by four of his mates, with a nasty wound in his side. The doctor dressed it hurriedly, and the man was carried off the field. The firing got hotter and another man fell. A bullet clipped a twig off a tree overhead and another splashed on the stone wall just in front of us. Crash went a volley from our Martini-Enfields in front, and crash with a somewhat deeper sound came an answering volley from the 
Sniders and Springfields of our white-capped foes, whom we rarely by any chance saw, so dense was the forest and so thick their stone wall. And all the time there was a continuous fusillade of stray shots. A rebel volley sounded more to our right. Were we going to be outflanked? Both sides were pumping lead now with a vengeance. Gaunt's 120 was being thinned out. It was apparent that they could not take the second fort. (M. Ross, 1899t)

It was after one of Ross's despatches in April depicting the bombardment of Samoan villages by British and US warships that Wellington's Evening Post came out strongly against what was happening in Samoa, calling it an 'international scandal'. The following editorial, which appeared on 29 April under the heading The Samoan scandal, was incandescent in its rage against the bombardment 'from which the three Powers concerned can hardly emerge with ought but discredit'.

Apart from the evident desire of our naval men from the first to 'have a smack at' somebody, and the uncompromising attitude of the German officials, the organised attacks upon the Samoans by the united British and American forces have been both inglorious and ineffective. But the most deplorable, if not barbarous, part of the whole business has been the wanton destruction of the lives and property of the natives by the combined warships of the English speaking powers along the whole line of coast within reach of modern naval artillery. (Anonymous, 1899p)

The Press, in comparison to The Observer and Evening Post, was much more muted in its view of the 'troubles' in Samoa. This was not to say the paper didn't follow the events there with any less interest - in the course of about five months The Press ran 11 leaders on the topic. The paper's criticism was more measured. For example, this from a leader on the Berlin Treaty which had established the form of government reigning in Samoa:

It is safe to say that in the whole history of diplomacy a more ridiculous arrangement was never before made, and a more farcical form of government was never set up. (Anonymous, 1899x)

The Press leaders complained about British 'indifference', 'apathy' and 'supineness' and the 'nobility' of the Samoan people and regretted the 
bloodshed but not in such forceful and condemning tones as the other two papers (Anonymous, 1898, 1899d, 1899f, 1899g, 1899h, 1899i, 1899n, $1899 \mathrm{~s}, 1899 \mathrm{x})$. The $N Z$ Herald was similarly more restrained in its view of the 'troubles' in Samoa. Its many leading articles also criticised the Berlin Treaty and urged Premier Seddon to assume the lead in getting 'a united representation from all the Australasian colonies' and 'in a respectful but forcible way' point out to the Secretary of State the impossibility of securing peaceable government in Samoa under the Treaty of Berlin. The treaty had 'broken down'. The situation would never be settled 'so long as three powers insist upon having a hand in the administration of affairs' (Anonymous, 1899a, 1899j). In April Ross's reports show no signs of losing impetus (M. Ross, 1899a, 1899b, 1899g, 18991, 1899m, 1899v, 1899x, 1899z) and more despatches followed in May when the commission of three, representing the US, Britain and Germany, was sent out to investigate the situation and report back. Ross was plainly unhappy about the order to cease hostilities and keen to see the fighting continued.

The Moana, which arrived from New Zealand on the 21 st of April,
brought news of the appointment of a High Commission to inquire
into the Samoan troubles. In the meantime, however, the position had
been further aggravated by the attitude and actions of the rebels. The
news that there was to be a cessation of hostilities there for came at
a very inopportune moment. Just, in fact, as the rebels were on the
point of being thoroughly whipped. In another week or 10 days the
Americans and the British would have solved the difficulty, the rightful
King would have been secure on the throne, the Supreme Court and
the Berlin Treaty upheld, and the peace of Samoa practically assured
for many years to come. (M. Ross, 1899r)

By early May Ross was winding down his despatches as an armistice was declared (M. Ross, 1899f, 1899h, 1899k, 1899s, 1899t, 1899u). His final report from Samoa was published in the $O D T$ on 20 May and ran over two and a half columns or around 5500 words. He began it by quoting Rudyard Kipling's 'Take up the white man's burden'. This appears to be an account from an earlier despatch and is written in quite a light hearted manner, with further quotes from poems sprinkled throughout. He intersperses factual chronicling of the carnage of war with lyrical descriptions of the countryside.

174 PACIFIC JOURNALISM REVIEW 14 (2) 2008 


\begin{abstract}
Already some of our men are lying 40 fathoms deep outside the reef, and others, officers and men, with severed heads, are resting beneath the painted headboards of a new cemetery in Mulinuu, heedless alike of bugle calls, the crash of the Nordenfeldts, or the booming of the big 6 inch guns. The night is inky black, but the searchlights of the warships send their long gleaming fingers athwart the bay, and houses and palms and the white surf on the outer reefs are every now and then revealed with startling suddenness from out of the gloom of the tropic night. The talea trees stand stiff by the roadside, the fronds of the tall palms wave gently in the night air, or a ripe mango flops down beside us, challenged every few yards, we walk on. The waves of the great lagoon come to the very street, and between their everlasting sighing we can hear the distant diapason of the long Pacific rollers as they churn themselves into foam on the outer reef.
\end{abstract}

This is the leisurely, long winded style so beloved of the time and of which Ross was an adherent par excellence. Ross also took photographs while in Samoa and some of these were published in New Zealand papers. For example, a montage of photos was published in the Weekly Press (M. Ross, 1899j). It is presumed that Ross returned to New Zealand in time for the next session of Parliament.

\title{
Resolution of the 'troubles'
}

It was not until 10 November 1899 that New Zealand heard by cable that the three commissioners, Freiherr Speck von Sternberg, (Germany), C.E.N. Elliott (Britain) and Bartlett Tripp (US), had agreed on a settlement for Samoa. The 'irrational outcome of this litany of failures', as Steven Fischer called it, (Fischer, 2002, p. 145) was the division of Samoa into two separate legal entities: with Germany taking the western part of Samoa and the US taking the east (Anonymous, 1899e). A few newspaper editors shared Seddon's views that the news of the Samoan settlement was 'an unwelcome surprise' and regretted the loss of the 'Paradise of the Pacific' (A. Ross, 1964, p. 252). For example, The Observer, in a leader on 18 November 1899, said that it was wrong to claim Germany's acquisition of Samoa did not prejudice New Zealand's interests.

It is a commercial axiom that trade follows the flag and, seeing that New Zealand has had the lion's share of colonial trade with Samoa, 
and it is for that reason New Zealand's right, and a duty she owes to herself, to ask for some consideration in any arrangement the Imperial government might make.... Her history has to some extent been bound up with that of Samoa. She is Samoa's closest neighbour and by virtue of these facts and her proffers of practical help when the Empire was engaged in quelling internecine war at Samoa, New Zealand has an undoubted right, as an integral part of the Empire, to express to the Imperial Government her mind upon this arrangement that has been sprung upon us with such startling surprise. (Anonymous, 1899o)

The Evening Post detailed the settlement in a leader but in very muted tones considering the passion with which it had earlier condemned the actions by the three powers in the island nation (Anonymous, 1899q). The NZ Herald was also restrained in its comments on the announcement of the partition, but lamented the colonies not being consulted.

\begin{abstract}
....in view of the colonies of Australasia it was of importance to Great Britain that no other Power should establish itself in these seas. We were in hopes that a settlement might be made by the British Government buying up the German interests in Samoa. But apparently that could not be done. We do not know whether the British Government has taken any means before concluding this agreement to satisfy itself as to the feeling in these colonies. We think that in such a matter it ought to have done so. (Anonymous, 1899w)
\end{abstract}

Other papers carried news of the settlement buried amongst cables about the South African war, to which New Zealand troops had been despatched in late October (Anonymous, 1899e).

\title{
Comment on Ross's despatches
}

From the time he first got to Samoa Ross worked assiduously to provide detailed coverage of the disturbances in Samoa. It was clear few obstacles were put in his way in regards to gathering information and none in what he wrote. There was no censorship. He talked to all the leading figures in the conflict, wrote graphically about the fighting and was able to deliver his despatches to his reading public promptly enough that the news was not stale when they read it. He was never so free again in his war reporting. As with most of his writing, he chose the narrative or chronological style, and often 
wrote in a florid and, to a modern mind, long winded manner. This was not an unusual style of journalism.

\begin{abstract}
Before the end of the 19th century, journalist historians agree, stories were almost always told in the traditional, slow-paced (some might say long-winded) way. Whether they were fairy tales or newspaper accounts, they began with a signal that something important, useful, inspiring or entertaining was about to begin ('Once upon a time'). The narrator, or storyteller, started at the beginning and continued to the end, leaving the outcome until the last ('And they lived happily ever after'). (Scanlan, 2002)
\end{abstract}

In fact, Scanlan cites William Howard Russell's leisurely style of writing his Crimean War reports where there was no sense of urgency because of the time it would take for the despatch to get to its destination. The personal pronouns did figure frequently in Ross's accounts. He talked about 'our friendlies', 'our guns' and used 'I' and 'we' often. His introductions were still very wordy and complex but he did make some attempt occasionally to try and summarise the main angle in them. Michael Schudson has explained that the summary lead and inverted pyramid structure were not common elements in journalism of the 19th century (Michael Schudson, 1995, pp. 55-56). Ross, because he was often quite close to the firing line, was able to quote officers' orders to their men as they were engaged in fire fights. This gives an impression of immediacy to the accounts. Ross's despatches were all very long, but that was no different from the despatches of Rollett, the NZ Herald's man in Apia. In some of his reports Ross could not forebear proffering his own opinion on the state of affairs he had been witnessing. When he did, these opinions were largely reflective of those of the New Zealand government and of the leading daily newspapers such as The Press, NZ Herald and the ODT. The Evening Post appeared to be the only major paper which held a more oppositional view of the conflict. Ross initially interviewed all the major players in the Samoan 'troubles' but after that concentrated solely on reporting from the one side. He allied himself firmly with the British and Americans, and the Malietoa party. The British or American soldiers were always 'brave', 'daring', 'cool', 'fearless' or 'bold' in action. 


\section{Conclusion}

The intervention of the three powers into the affairs of Samoa had serious and long lasting repercussions for the Samoan people. While New Zealand newspapers and the New Zealand government appeared sympathetic to the plight of their island neighbours they were unable to play any significant part in determining their fate. They were only able to offer comment from the sidelines. While some were incensed at the powers' treatment of the Samoans, it appeared that it was mainly self interest which motivated the New Zealand view. With Samoa in British hands, it was believed, trade with Samoa would be safe guarded, a strategic bulwark would be provided in the Pacific against any unfriendly incursions from other countries and the white population of the islands protected. The welfare of the Samoan people appeared of lesser importance, although some papers did show some concern for their situation. By the time the partition of Samoa was announced in November New Zealand's attention had been diverted to its participation in the South African war and so the announcement was greeted with a fairly muted response. Partition had always been discussed as an alternative so should not really have come as too much of a surprise however hopeful New Zealand might have been for a British solution.

What of Malcolm Ross's efforts in Samoa? He initiated his assignment to Samoa which says something for his understanding of newsworthy events and his desire to be there to report them. That is laudable in a journalist. It could almost be considered 'brave', 'bold' and 'fearless'! He was fortunate that he was not needed for his parliamentary duties because the House was in recess. In the time he was away he wrote thousands of words on the Samoan 'troubles', largely from the British, and so New Zealand, point of view. He allied himself firmly with the British military and was permitted to accompany officers on many of their missions and was often in the thick of the fighting. Ross would never again have such license and never again would he have the freedom to write whatever he pleased. His despatches were lengthy affairs, minutely detailed, and often with graphic depiction of beheadings, looting and other carnage of war interspersed with flights of literary fancy extolling the beauty of the surroundings. He did not tend to romanticise war, however. His reports were liberally sprinkled with the personal pronouns as they were with his own thoughts and opinions about the events he was witnessing. Rollett, the NZ Herald man, also wrote long pieces, proffered his opinion 
and occasionally used the personal pronoun, so Ross was not alone in that. His writing did not differ in style from any other sort of writing he had done before going to Samoa. His despatches were merely an identifiable extension of his usual form of journalism which had been formulated over the years since joining the $O D T$ in 1881 . One would therefore expect little change in his journalism in the future.

\section{References}

Anonymous. (1878, 1878/08/12). Our public men. North Otago Times, p. 2.

Anonymous. (1882, 1882/11/29). Archibald Forbes in New Zealand. Hawera and Normanby Star, p. 2.

Anonymous. (1883, 1883//06/23). Local and general. Otago Witness, p. 8.

Anonymous. (1884, 1884/10/11). Mr Howard Vincent. Evening Post, p. 2.

Anonymous. (1885, 1885/10/03). Passing notes. Otago Witness, p. 17.

Anonymous. (1888a, 1888/11/30). A celebrated war correspondent-and interview with Mr Phil Robinson. Otago Witness, p. 8.

Anonymous. (1888b, 1888/12/22). Experiences of a war correspondent. Evening Post, p. 2.

Anonymous. (1888c, 1888/11/29). An interview with Mr Phil Robinson. Evening Post, p. 4.

Anonymous. (1890a, 1890/02/27). Looking at war. Otago Witness, p. 34.

Anonymous. (1890b, 1890/04/02). Mr David Christie Murray-“Looking at war". Evening Post, p. 2.

Anonymous. (1892, 1892/01/07). The Stanley lectures- 'How I found Livingstone'. Evening Post, p. 2.

Anonymous. (1895, 1895/04/19). A notable visitor. Evening Post, p. 2.

Anonymous. (1895-1901). Board of directors minute book 1895-1901 AG 632 2/3

Unpublished manuscript, Hocken Library, Dunedin.

Anonymous. (1898, 1898/12/16). Germany and Samoa. The Press, p. 4. Anonymous. (1899a, 1899/01/21). Affairs of Samoa. NZ Herald, p. 4.

Anonymous. (1899b, 1899/04/08). April foolery and colonial jingoism.

The Observer, p. 2.

Anonymous. (1899c, 1899/04/03). Auckland volunteers for Samoa. The Press, p. 4. Anonymous. (1899d, 1899/03/30). The bombardment of Samoa. The Press, p. 5.

Anonymous. (1899e, 1899/11/18). The fate of Samoa-relinquished by BritainGerman concessions. Northern Advocate, p. 2.

Anonymous. (1899f, 1899/01/25). Germany and Samoa. The Press, p. 4.

Anonymous. $(1899 \mathrm{~g}, 1899 / 04 / 14)$. How the Germans came to Samoa

The Press, p. 4.

Anonymous. (1899h, 1899/02/02). The news from Samoa. The Press, p. 4. Anonymous. (1899i, 1899/01/21). Samoa. The Press, p. 6.

Anonymous. (1899j, 1899/01/23). Samoa and the Powers. NZ Herald, p. 4. 
Anonymous. (1899k, 1899/05/25). The Samoa trouble- 'loyal New Zealand'. Otago Daily Times, p. 6.

Anonymous. (18991, 1899/04/08). The Samoan bungle-how not to govern. The Observer, p. 2.

Anonymous. (1899m, 1899/04/05). The Samoan muddle. Evening Post, p. 5.

Anonymous. (1899n, 1899/04/04). The Samoan people-the Native Minister and of the Samoans. The Press, pp. 4-5.

Anonymous. (1899o, 1899/11/18). The Samoan question-the national ass. The Observer.

Anonymous. (1899p, 1899/04/29). The Samoan scandal. Evening Post, p. 4. Anonymous. (1899q, 1899/11/10). The Samoan settlement. Evening News, p. 4. Anonymous. (1899r, 1899/04/01). The Samoan situation Evening Post, p. 6. Anonymous. (1899s, 1899/04/13). The situation in Samoa. The Press, p. 5. Anonymous. (1899t, 1899/01/19). Untitled. NZ Herald, p. 1. Anonymous. (1899u, 1899/04/10). Untitled. Evening Post, p. 5. Anonymous. (1899v, 1899/04/22). Untitled. The Observer, p. 4. Anonymous. (1899w, 1899/04/03). Untitled. NZ Herald, p. 4. Anonymous. (1899x, 1899/01/19). The war in Samoa. The Press, p. 4. Anonymous. (1899y, 1899/04/06). The war in Samoa - a tripartite commission to be set up. The Press, p. 5.

Anonymous. (1900, 1900/08/28). War correspondents. Otago Daily Times. Anonymous. (1907, 1907/08/17). Untitled. The Observer, p. 5.

Anonymous. (2000). War correspondents. In I. McGibbon (Ed.), The Oxford companion to New Zealand military history (pp. 578-580). Auckland: Oxford University Press.

Barclay, G. (1978). A history of the Pacific-from the Stone Age to the present day. London: Sidgwick \& Jackson.

Blomfield, W. (1899, 1899/01/23). Too many cooks spoil the broth. The Observer, p. 1.

Campbell, I. C. (1989). A history of the Pacific islands. Christchurch: Canterbury University Press.

Featon, J. (1879). The Waikato War, 1863-4. Auckland: J. Wickham.

Fischer, S. R. (2002). A history of the Pacific islands. Basingstoke, New York: Palgrave.

Governor. (1899). Untitled. In B. Government (Ed.) (Telegram ed.).

Hansard. (1899). NZ Parliamentary debates (Vol. 106). Wellington: New Zealand Government.

McGibbon, I. (Ed)(2000). The Oxford companion to New Zealand military history. Auckland: Auckland University Press

Morris, N. (Ed.). (1963). The journal of William Morgan : Pioneer settler and Maori War correspondent (Reprint 1999 ed.). Christchurch: Cadsonbury.

Ross, A. (1964). New Zealand aspirations in the Pacific in the 19th century. Oxford: Clarendon Press 
Ross, M. (1899a, 1899/04/01). The bombardment of Samoa. Evening Post, p. 5.

Ross, M. (1899b, 1899/04/29). The crisis in Samoa. The Press, p. 10.

Ross, M. (1899c, 1899/03/17). The crisis in Samoa. Otago Daily Times, p. 6.

Ross, M. (1899d, 1899/03/18). The crisis in Samoa. Otago Daily Times, p. 5.

Ross, M. (1899e, 1899/03/18). The crisis in Samoa-affairs still very unsettled-more fighting feared. The Press, p. 10.

Ross, M. (1899f, 1899/05/08). The crisis in Samoa-cessation of hostilities ordered - the fighting had Vailima-losses of the enemy. The Press, p. 5.

Ross, M. (1899g, 1899/04/28). The crisis in Samoa-further severe fightingMataafa's followers repulsed. The Press, pp. 5-6.

Ross, M. (1899h, 1899/05/10). The crisis in Samoa-the armistice. The Press, p. 6.

Ross, M. (1899i, 1899/02/15). The crisis in Samoa-a state of anarchy-scenes of the war - the British navy insulted. The Press, pp. 5-6.

Ross, M. (1899j, 1899/02/22). The disturbance in Samoa. The Weekly Press, pp. 8-9.

Ross, M. (1899k, 1899/05/20). Empire builders in Samoa-scenes and incidents of the war. Otago Daily Times, p. 2.

Ross, M. (18991, 1899/04/12). Further bloodshed in Samoa. Evening Post, p. 5.

Ross, M. (1899m, 1899/04/13). Punitive proceedings at Samoa-the action of the Anglo-American forces. Evening Post, p. 5.

Ross, M. (1899n, 1899/03/15). The Samoan crisis. Otago Daily Times, p. 7.

Ross, M. (1899o, 1899/03/04). The Samoan crisis. Otago Daily Times, p. 2.

Ross, M. (1899p, 1899/02/15). The Samoan crisis-a state of anarchy and dissatisfaction-extraordinary actions of the president and provisional government. Otago Daily Times, p. 4.

Ross, M. (1899q, 1899/03/08). The Samoan crisis-action of the Provincial Government—high handed proceedings—apology from Dr. Raffel. The Press, p. 5.

Ross, M. (1899r, 1899/05/05). The Samoan crisis—the battle of Lotopa. Otago Daily Times, p. 6.

Ross, M. (1899s, 1899/05/11). The Samoan trouble-the armistice. Otago Daily Times, p. 6.

Ross, M. (1899t, 1899/05/10). The Samoan war-sharp fighting with the rebels. Otago Daily Times, p. 6.

Ross, M. (1899u, 1899/05/10). The situation in Samoa-the rebels vacate their fortifications. Otago Daily Times.

Ross, M. (1899v, 1899/04/01). The war in Samoa. The Press, p. 8.

Ross, M. (1899w, 1899/03/30). War in Samoa. Otago Daily Times, p. 6.

Ross, M. (1899x, 1899/04/13). The war in Samoa-further fighting-a serious reverse. The Press, p. 5.

Ross, M. (1899y, 1899/03/30). War in Samoa-Mataafa defies the powers and begins the fighting - bombardment of Upolu. The Press, pp. 5-6.

Ross, M. (1899z, 1899/04/14). The war in Samoa-our correspondent's experiences -on a punitive expedition-discouraging the rebels. The Press, p. 5. 
Russell, W. H. (1855). The war-from the landing at Gallipoli to the death of Lord Raglan (First ed.). London: George Routledge \& Co.

Scanlan, C. (2002). Reporting and Writing: Basics for the 21st Century: Oxford University Press.

Scholefield, G. H. (1958). Newspapers in New Zealand. Wellington: A.H. \& A.W. Reed.

Schudson, M. (1995). The politics of narrative form. In The power of news (pp. 53-71). Cambridge, Mass. London: Harvard University Press.

Schudson, M. (1995). Question authority: A history of the news interview.

In The power of news (pp. 72-93). Cambridge, Mass.: Harvard University Press.

Allison Oosterman is a lecturer in journalism and a doctoral candidate at AUT University. An earlier version of this article was presented at the Australian Media Traditions conference in Ballarat, Victoria, in November 2007. allison.oosterman@aut.ac.nz

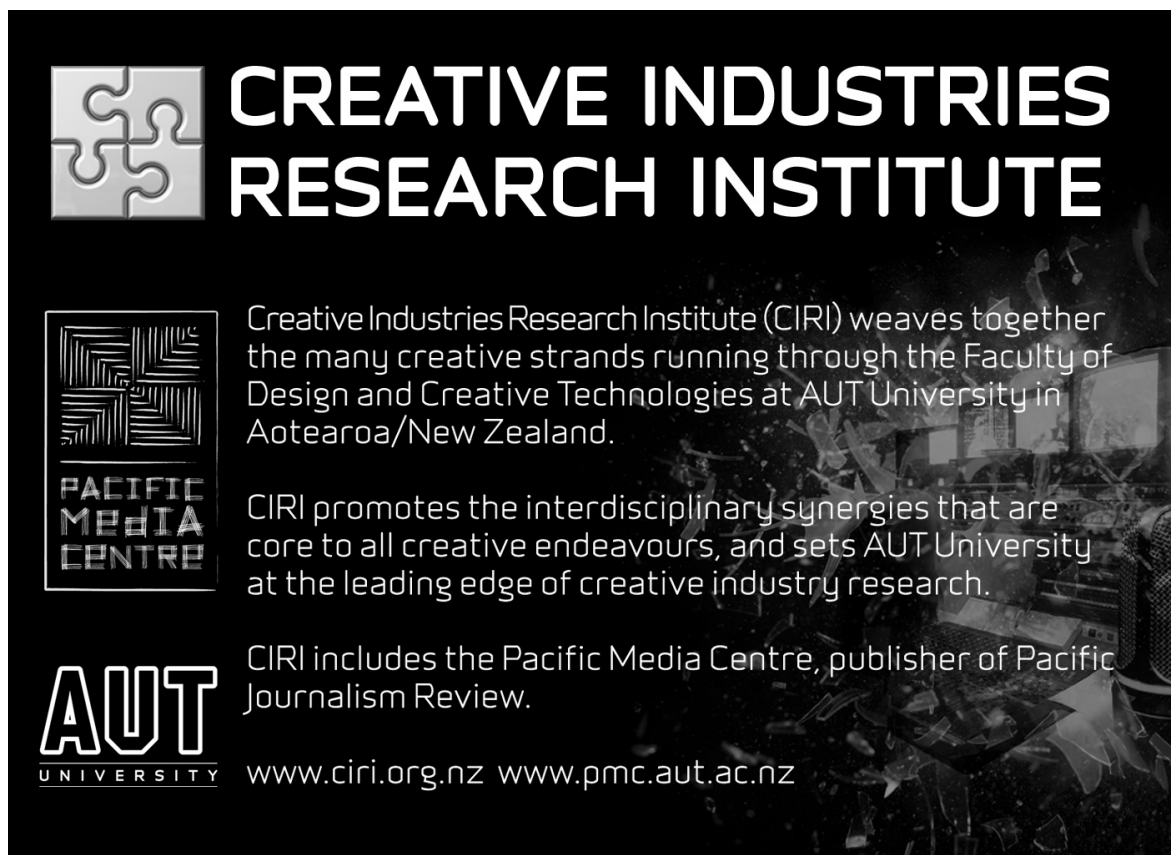

